\title{
Ontogenetic changes in the feeding strategy of Lepidonotothen nudifrons (Pisces, Nototheniidae) off the South Shetland Islands and the Antarctic Peninsula
}

\author{
Gabriela Blasina (10) ${ }^{\mathrm{a}, \mathrm{b}}$, Andrea Lopez Cazorla ${ }^{\mathrm{a}, \mathrm{b}}$, Mariana Deli Antoni ${ }^{\mathrm{c}, \mathrm{d}}$, Daniel Bruno ${ }^{\mathrm{e}}$, Matías Delpiani ${ }^{\mathrm{c}, \mathrm{d}}$ \\ \& Juan Martín Díaz de Astarloa ${ }^{c, d}$
}

\begin{abstract}
aLaboratorio de Vertebrados, Departamento de Biología, Bioquímica y Farmacia, Universidad Nacional del Sur (UNS), Bahía Blanca, Argentina; ' Instituto Argentino de Oceanografía, Consejo Nacional de Investigaciones Científicas y Técnicas (CONICET)/Universidad Nacional del Su (UNS), Bahía Blanca, Argentina; Instituto de Investigaciones Marinas y Costeras, Consejo Nacional de Investigaciones Científicas y Técnica (CONICET)/Universidad Nacional de Mar del Plata (UNMdP), Mar del Plata, Argentina; ${ }^{\mathrm{d} G r u p o ~ d e ~ B i o t a x o n o m i ́ a ~ M o r f o l o ́ g i c a ~ y ~ M o l e c u l a r ~ d e ~}$ Peces, /Universidad Nacional de Mar del Plata (UNMdP), Mar del Plata, Argentina; éaboratorio de Ecología, Fisiología y Evolución de Organismos Acuáticos, Consejo Nacional de Investigaciones Científicas y Técnicas (CONICET), Ushuaia, Argentina
\end{abstract}

\section{ABSTRACT}

The diet and feeding strategy of Lepidonotothen nudifrons off the South Shetland Islands and the Antarctic Peninsula, as well as their variation in relation to ontogenetic stage (juvenileadult) and sampling area, were determined by stomach contents analysis. Additionally, the trophic level of this species was estimated to determine its position within the Antarctic food web. Out of 247 specimens with prey in their stomachs, 144 were caught near the South Shetland Islands and 103 off the Antarctic Peninsula. Ontogenetic changes in the trophic ecology of $L$. nudifrons were observed in both areas and were mainly related to a decrease of copepods and an increase of euphausiids in the diet. The diet of juveniles from the South Shetland Islands was characterized by the dominance of calanoid copepods, followed by isopods and amphipods, whereas diet off the Antarctic Peninsula was dominated by amphipods and cyclopoid copepods. The diet in adults was dominated by amphipods and euphausiids in both areas. The specialization of individual predators on different prey types was observed when considering the whole population of $L$. nudifrons, but when ontogenetic stages were considered separately it showed a more mixed feeding strategy, with different dominant prey for each class. Although the trophic level increased with fish size, L. nudifrons can be classified as secondary consumer throughout its lifespan.

\section{KEYWORDS}

Antarctic fish diet; zonerelated changes; dominant prey; feeding strategy; trophic level; food web

\section{ABBREVIATIONS}

ANOVA: one-way analysis of variance test; AP: Antarctic Peninsula; NP-MANOVA: non-parametric permutation multivariate analysis of variance; SSI: South Shetland Islands; TR: trophic level

\section{Introduction}

Antarctic coastal fish communities are composed of species not found elsewhere in the world (Knox 2006). These communities are isolated and are, structurally and functionally, the result of millions years of co-adaptation and co-evolution among fish species (Eastman 2005). Current climate change, coupled with the impacts related to human activities, threatens the equilibrium and stability of Antarctic ecosystems. To evaluate the human activity effects on these ecosystems it is essential to know their structure and dynamic (Heath et al. 2012). Studying growth, reproduction and feeding habits of Antarctic fishes is necessary to understand their biology and ecology, as well as their relationship with other components in the Antarctic marine ecosystem (Kock et al. 2012).

Coastal Antarctic fish fauna is dominated by highly endemic species of the family Nototheniidae. These species have demersal lifestyles as adults, but develop from pelagic larvae (Eastman 2005). Generally, nototheniids occupy intermediate food web positions in the Southern Ocean (Kock et al. 2012) and have developed several feeding strategies to utilize different food resources in a variety of habitats (Targett 1981; Fanta \& Meyer 1998). They feed on both benthic and epibenthic invertebrates, and are preyed upon by other fishes, seals and birds (La Mesa et al. 2004). To determine the role of nototheniids in the Antarctic marine ecosystem is essential to understand the energy flow in its food web (Barrera-Oro 2003).

Lepidonotothen nudifrons (Lönnberg 1905) inhabits Antarctic waters between 3 and $400 \mathrm{~m}$ depths and is among the most abundant and broadly distributed demersal fish off the SSI and the AP (Llompart et al. 2015). Reaching a maximum size of $220 \mathrm{~mm}$ total length and attaining sexual maturity at four or five years of age, it is small and slow growing (Hourigan \& Radtke 1989). This species is ecologically important on account of its ecological role as predator and prey (Barrera-Oro 2002; La Mesa et al. 2004). The dietary composition of L. nudifrons has 
been previously reported from South Georgia and the South Orkney Islands (Targett 1981), the SSI (Barrera-Oro 2003) and the Danco Coast in the western AP (Casaux et al. 2003). In all these investigations, L. nudifrons was found to feed mainly on copepods, amphipods, polychaetes and shrimps. The diet of Antarctic fish is likely to vary considerably between years, especially in an environment in which one of the major prey items, such as krill, exhibit huge inter annual variability. Furthermore, feeding habits and diet composition of fish species can change during its ontogeny, as well as its role in the ecosystem (Moreira et al. 2014). However, comparative studies on feeding ecology of juvenile and adult stages, as well as regional pattern change, have not been carried out so far. The aims of this study were: (1) to provide new insights on the diet of L. nudifrons; (2) to compare the feeding habits and feeding strategy of juveniles and adults; and (3) to estimate their trophic level off the SSI and the AP, in order to determine both their position and ecological role within the Antarctic food web.

\section{Materials and methods}

A total of 269 specimens of $L$. nudifrons were collected off the SSI and the AP (Fig. 1). Of them, 156 were caught off the SSI, ranging between 63 and $178 \mathrm{~mm}$ total length (TL), and 113 off the AP, with a size range of 55-166 mm TL. Fish were caught during the 2011 Summer Austral Campaign of Argentina's National Scientific and Technical Research Council (Table 1), on board the Puerto Deseado oceanographic vessel, by a demersal bottom trawl pilot net with $25 \mathrm{~mm}$ mesh size. Fishing hauls were performed at a speed of 2-3 knots for 15 minutes and all the fish captured were identified following De Witt et al. (1990), counted and frozen at $-10^{\circ} \mathrm{C}$. Afterwards, individuals were measured to the nearest millimetre to determine $T \mathrm{~L}$ and standard length $(\mathrm{SL})$, weighted to the nearest $0.01 \mathrm{~g}$ $(W)$ and their stomach contents were removed. Specimens were classified in two size classes, according to the length at first maturity (Hourigan \& Radtke 1989): juvenile ( $\leq 93 \mathrm{~mm} \mathrm{SL})$ and adult fishes (>93 mm SL). Only specimens containing food in their stomachs were used for the diet analyses. Of them, 144 (72 juveniles and 72 adults) were caught off the SSI, ranging between 63 and $175 \mathrm{~mm} \mathrm{TL}$, and 103 (55 juveniles and 48 adults) off the AP, with a size range of 55-166 mm TL (Fig. 2).

The vacuity index $(I \mathrm{~V})$ and the stomach repletion index (ISR) were calculated for each sampling area. The $I \mathrm{~V}$ was calculated as: (number of empty stomachs/total number of stomachs examined) $\times 100$ (Molinero \& Flos 1992). ISR was calculated as: $(W f / W) \times 100$, where $W$ is the fish weight and $W f$ is the ingested food weight (Okach \& Dadzie 1988). A $t$-test was applied to analyse differences between ISR from both the SSI and the AP.

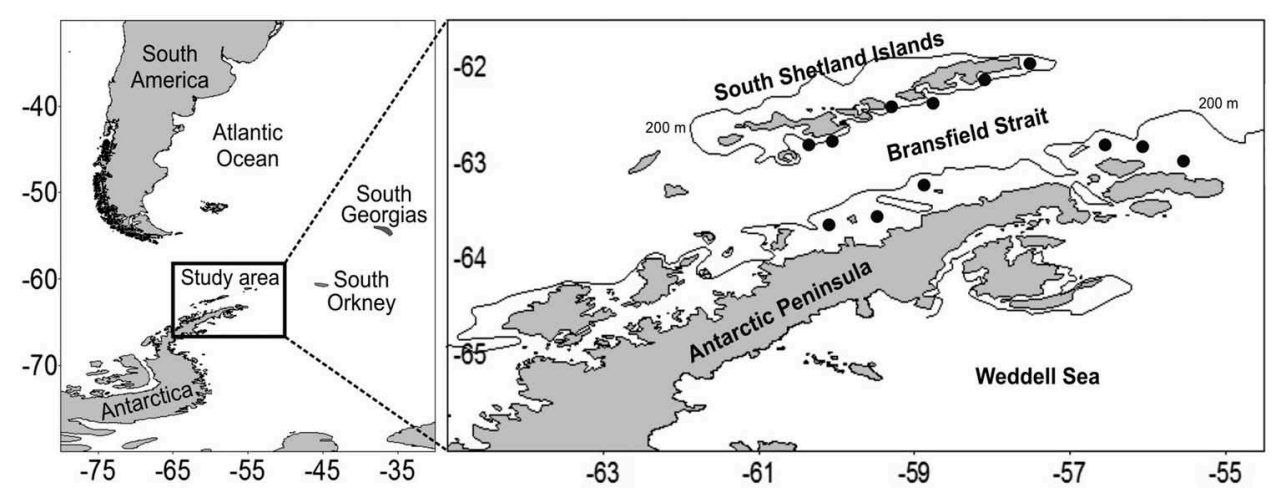

Figure 1. Sampling area, including the SSI and the AP. Black dots represent the stations where fishing hauls were performed.

Table 1. Details of the fishing hauls performed off the SSI and the AP.

\begin{tabular}{|c|c|c|c|c|c|c|c|}
\hline Date & Latitude & Longitude & Water temp. $\left({ }^{\circ} \mathrm{C}\right)$ & Salinity & Depth (m) & Juvenile $^{a}$ & Adult $^{\mathrm{a}}$ \\
\hline 17 February 2011 & $62^{\circ} 04.2^{\prime} \mathrm{S}$ & $57^{\circ} 29.3^{\prime} \mathrm{W}$ & 2.3 & 33.9 & 203 & 16 & 13 \\
\hline 17 February 2011 & $62^{\circ} 09.7^{\prime} \mathrm{S}$ & $58^{\circ} 03.4^{\prime} \mathrm{W}$ & 2.1 & 34.0 & 105 & 10 & 13 \\
\hline 19 February 2011 & $62^{\circ} 22.3^{\prime} \mathrm{S}$ & $58^{\circ} 53.9^{\prime} \mathrm{W}$ & 2.1 & 33.8 & 123 & 16 & 16 \\
\hline 20 February 2011 & $63^{\circ} 14.6^{\prime} \mathrm{S}$ & $58^{\circ} 46.3^{\prime} \mathrm{W}$ & 2.2 & 33.9 & 117 & 15 & 4 \\
\hline 20 February 2011 & $63^{\circ} 47.5^{\prime} \mathrm{S}$ & $59^{\circ} 26.0^{\prime} \mathrm{W}$ & 2.2 & 33.8 & 163 & 9 & 12 \\
\hline 21 February 2011 & $63^{\circ} 51.5^{\prime} \mathrm{S}$ & $60^{\circ} 15.5^{\prime} \mathrm{W}$ & 2.3 & 33.9 & 201 & 11 & 5 \\
\hline 24 February 2011 & $62^{\circ} 47.2^{\prime} \mathrm{S}$ & $60^{\circ} 12.3^{\prime} \mathrm{W}$ & 2.4 & 33.9 & 254 & 15 & 14 \\
\hline 24 February 2011 & $62^{\circ} 52.4^{\prime} \mathrm{S}$ & $60^{\circ} 35.6^{\prime} \mathrm{W}$ & 2.2 & 33.9 & 214 & 9 & 4 \\
\hline 25 February 2011 & $62^{\circ} 32.3^{\prime} \mathrm{S}$ & $59^{\circ} 17.4^{\prime} \mathrm{W}$ & 2.3 & 33.8 & 147 & 14 & 16 \\
\hline 27 February 2011 & $62^{\circ} 43.0^{\prime} \mathrm{S}$ & $56^{\circ} 32.0^{\prime} \mathrm{W}$ & 0.5 & 34.2 & 202 & 5 & 12 \\
\hline 27 February 2011 & $62^{\circ} 43.2^{\prime} \mathrm{S}$ & $56^{\circ} 29.8^{\prime} \mathrm{W}$ & 0.6 & 34.1 & 222 & 6 & 8 \\
\hline 27 February 2011 & $62^{\circ} 45.6^{\prime} \mathrm{S}$ & $55^{\circ} 37.2^{\prime} \mathrm{W}$ & 0.8 & 34.1 & 188 & 12 & 14 \\
\hline
\end{tabular}

${ }^{a}$ Number of fish collected on each collecting date. 


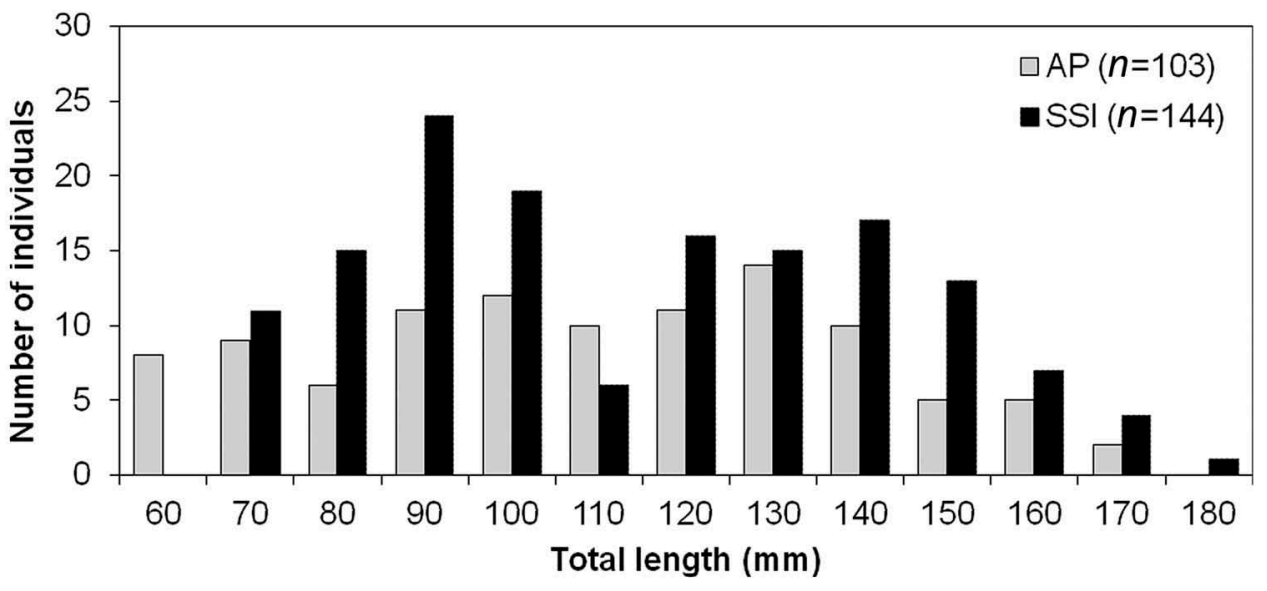

Figure 2. Length-frequency distributions of 247 individuals of Lepidonotothen nudifrons with stomach content from the SSI and the AP.

Prey were identified to the lowest possible taxonomic level according to Boltovskoy (1999) and each prey item was counted and weighed $( \pm 0.01 \mathrm{~g})$. The importance of each prey item was calculated with the index of relative importance (IRI) from the equation $I \mathrm{RI}=\% O \times(\% \mathrm{~N}+\% W)$, where $\% O$ is frequency of occurrence, $\% \mathrm{~N}$ is percentage by number and $\% W$ is percentage by wet weight (Pinkas et al. 1971; Hyslop 1980). IRI values were thus standardized to $100 \%$ (\% IRI) (Cortés 1997). For the statistical analyses, prey items were grouped into main taxonomical groups.

Ontogenetic and areas-related changes in diet were assessed using multivariate analysis on the number and weight of the main prey categories consumed. A non-metric multi-dimensional scaling of Bray-Curtis similarity measures (Zuur et al. 2007) was performed to order fish in a two-dimensional plane according to their relevant diet similarity. The relative and interactive effects of ontogenetic stage and areas were tested by a two-way NP-MANOVA using BrayCurtis distances with 10000 permutations of the data matrix (Anderson 2001). If significant differences were detected, a posteriori pairwise comparisons were made (Anderson 2001). All statistical analyses were performed using $\mathrm{R}$ statistical software (R Development Core Team 2012).

Feeding strategy, niche width contribution and dominance of each prey category in the diet of $L$. nudifrons were assessed with a modification of the Costello graphical method (Costello 1990; Amundsen et al. 1996). In the graphical method, prey-specific abundance $(\% P)$ is plotted against the frequency of occurrence $(\% O)$, providing a two-dimensional diagram (Amundsen et al. 1996). The number of each prey taxon was used to calculated $\% P$ :

$$
\% P:\left(\sum^{A} i / \sum^{A} t\right) \cdot 100
$$

where $P$ is the prey-specific abundance, $A i$ is the abundance of prey $i$ in stomach contents and $A t$ is the total prey abundance considering only those predators in which the prey $i$ occurs. In accordance with Amundsen et al. (1996), prey importance is represented by the diagonal set from the lower left to the upper right, with dominant prey at the upper and rare prey at the lower end. Prey located at the upper right of the diagram would indicate a narrow niche breadth (i.e., a specialized predator), but if most prey points are located along or below the diagonal, the trophic niche breadth would be broad (i.e., generalist predator). Prey located on the upper left corner of the graph indicate specialized individual predators, while prey on the lower right corner are eaten occasionally by most individuals in the population (Fig. 3). This graphical method was performed for each area and ontogenetic stage.

The TR of L. nudifrons, was estimated for the whole population, size class and sampling area, according to Cortés (1999), as:

$$
T R: 1+\left(\sum_{j-1}^{n} P_{j} \cdot T R_{j}\right)
$$

where $T R_{j}$ is the $T R$ of each prey item and $P \mathrm{j}$ is the proportion of each prey item in the fish diet. The TRj values for each prey item were obtained from Cortés (1999), Pauly et al. (2000) and Ebert and Bizzarro (2007) (Table 2). ANOVA was used to examine the TR differences and a posteriori pairwise comparisons were made with a Tukey honest significant difference test (Zar 2010).

\section{Results}

The vacuity index of $L$. nudifrons was relatively low in both areas, being 7.65 and $9.71 \%$ off the SSI and the AP, respectively. Stomach repletion index was moderate, $1.58 \pm 0.95$ off the SSI and $1.69 \pm 1.02$ off the AP, and no significant differences between them were found $(t=0.778, p$ value $=0.437)$. Diet composition of $L$. nudifrons showed higher prey numbers in the SSI than 


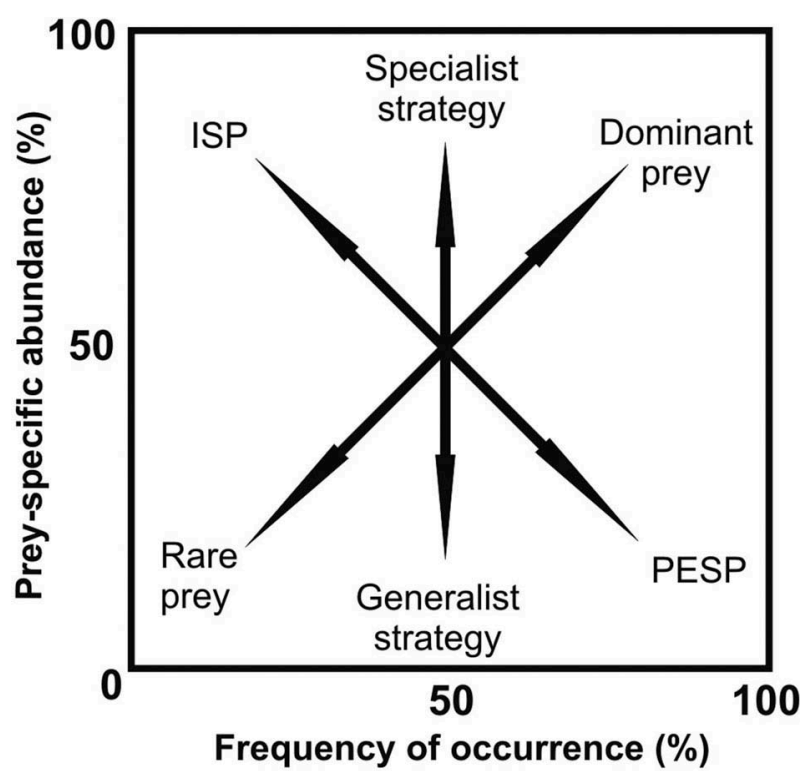

Figure 3. Explanatory diagram for the interpretation of feeding strategy, niche width contribution and importance of prey items. ISP: individual specialization of predators; PESP: individuals in the population eating several different prey items. Modified from Amundsen et al. (1996).

Table 2. $T R_{j}$ of Lepidonotothen nudifrons prey items.

\begin{tabular}{lll}
\hline Prey items & $T R_{j}$ & \multicolumn{1}{c}{ Reference } \\
\hline Polychaetes & 2.6 & Ebert \& Bizzarro 2007 \\
Molluscs (excluding cephalopods) & 2.1 & Cortés 1999 \\
Pycnogonids & 2.5 & Cortés 1999 \\
Copepods & 2 & Pauly et al. 2000 \\
Ostracods & 2.25 & Ebert \& Bizzarro 2007 \\
Amphipods and isopods & 2.52 & Cortés 1999 \\
Euphausiids & 2.25 & Cortés 1999 \\
\hline
\end{tabular}

in the AP, yielding 26 and 20 prey taxa, respectively. The most important zoological categories in both areas were amphipods, isopods, copepods, polychaetes and euphausiids (Table 3). Some of the main prey items exhibited considerable variation between areas and ontogenetic stages. In the SSI, the most important prey items in juveniles' diet were calanoid copepods, followed by the isopod Serolis sp., polychaetes and amphipods, while in adults' diet, amphipods and isopods showed the highest importance, followed by euphausiids and polychaetes. Off the AP, in contrast, the main food items in the diet of juveniles were amphipods and cyclopoid copepods, while in adults, the euphausiid Euphausia superba showed higher importance, followed by amphipods, polychaetes and isopods (Table 3).

Based on the numerical abundance of prey categories, individuals of $L$. nudifrons showed a clear separation between ontogenetic stages, but there was no clear trend between areas. Juveniles of each area were segregated, while the adults overlapped each other (Fig. 4). The NP-MANOVA test (for both number and weight) evidenced an interaction between ontogenetic stages and areas, where only juveniles showed significant differences in their diet (Table 4).
The feeding strategy of $L$. nudifrons seems to be both generalist (for prey positioned in the lower part of diagram) and specialist (for prey positioned in the upper part of diagram). Considering the general population in both areas, the high prey specific abundance and low occurrence of copepods, amphipods and euphausiids indicates a high between-phenotype component, with different individual groups relying on a small number of prey items which are different for each group (Fig. 5a, b). However, when ontogenetic stages and sampling areas were considered separately, L. nudifrons showed a more mixed strategy, varying between predators specializing on one prey and several individuals in the population eating several different types of prey. In juveniles' diet, amphipods and copepods were the dominant prey items; however, a different pattern was detected in the frequency of these prey from each area. Amphipods were more frequently consumed off the AP than off the SSI and isopods were more frequently consumed off the SSI than off the AP (Fig. 5c). Adults' diet in both areas was dominated by euphausiids and amphipods (Fig. 5e and 5f).

TR for the total population of L. nudifrons was $3.34 \pm 0.03$. Ontogenetic differences were found in TR (ANOVA $F$ value $=2130 ; d f=3$ and $396 ; p$ value $=0.0002)$, pointing out an increase of TR with fish size (juveniles' $\mathrm{TR}=3.22 \pm 0.01$; adults' $^{\prime}$ $T R=3.51 \pm 0.01 ; t=84.79, p$ value $<0.001)$. There was no difference in TR between areas for juveniles $(t=2.004, p$ value $=0.860)$ as well as for adults $(t=1.453, p$ value $=0.551)$.

\section{Discussion}

This study represents a comprehensive assessment of the feeding ecology of L. nudifrons off the SSI and the $\mathrm{AP}$, and the first evaluation of the effect of the ontogenetic variability in diet composition, feeding strategy and TR. The size range of individuals sampled in the SSI and the AP was similar to those previously reported from the AP (Daniels 1982), South Georgia and the South Orkney Islands (Targett 1981). The low $I V$ and the moderate ISR of L. nudifrons observed off the SSI and the AP during summer are in agreement with those mentioned for L. larseni in the same study area (Curcio et al. 2014), for L. squamifrons in South Georgia (Gregory et al. 2014) and elsewhere for other notothenioids (Bushula et al. 2005; Barrera-Oro \& Winter 2008; Moreira et al. 2014).

Consisting mainly of polychaetes, gammarian amphipods, isopods, copepods and krill, the food preferences of $L$. nudifrons found in the present study agree with those observed by several authors (Targett 1981; Takahashi \& Iwami 1997; Barrera-Oro 2003; Casaux et al. 2003). However, L. nudifrons presented spatial differences in diet composition among different areas: 
Table 3. Juvenile and adult diet composition of Lepidonotothen nudifrons caught off the SSI and the AP shown as number of individuals $(n)$, percentage frequency of occurrence $(\% O)$, percentage by number $(\% N)$, percentage by wet weight $(\% \mathrm{~W})$ and per cent index of relative importance (\%/RI).

\begin{tabular}{|c|c|c|c|c|c|c|c|c|c|c|c|c|c|c|c|c|}
\hline \multirow[b]{3}{*}{ Prey items } & \multicolumn{8}{|c|}{ South Shetland Islands } & \multicolumn{8}{|c|}{ Antarctic Peninsula } \\
\hline & \multicolumn{4}{|c|}{ Juvenile $(n=72)$} & \multicolumn{4}{|c|}{ Adult $(n=72)$} & \multicolumn{4}{|c|}{ Juvenile $(n=55)$} & \multicolumn{4}{|c|}{ Adult $(n=48)$} \\
\hline & $\% O$ & $\% N$ & $\% W$ & $\% / R I$ & $\% O$ & $\% N$ & $\% W$ & $\% / \mathrm{RI}$ & $\% O$ & $\% N$ & $\% W$ & $\% / \mathrm{RI}$ & $\% O$ & $\% N$ & $\% W$ & $\% / R I$ \\
\hline Hydrozoa & & & & & 4.4 & 0.8 & 0.9 & 0.3 & & & & & & & & \\
\hline Nemertea & & & & & 1.5 & 0.3 & 1 & 0.1 & & & & & & & & \\
\hline Polychaeta & 21.5 & 4.1 & 17.8 & 14.8 & 20.6 & 5.7 & 13.3 & 16.7 & 13.2 & 2.3 & 14 & 9.1 & 20 & 8.5 & 11.4 & 13.6 \\
\hline \multicolumn{17}{|l|}{ Mollusca } \\
\hline Margarella sp. & & & & & 3.2 & 0.5 & 0.6 & 0.1 & & & & & & & & \\
\hline Teledonia major & & & & & 4.3 & 0.8 & 1.4 & 0.4 & & & & & 10 & 3.7 & 7.5 & 3.8 \\
\hline Laternula elliptica & & & & & 4.6 & 1.6 & 1.9 & 0.7 & & & & & & & & \\
\hline Pycnogonida & & & & & 2.9 & 0.8 & 1.8 & 0.3 & 3.8 & 1.6 & 4 & 0.6 & 5 & 2.2 & 2.3 & 0.8 \\
\hline \multicolumn{17}{|l|}{ Copepoda } \\
\hline Calanoida & 23.1 & 52 & 9.8 & 43.8 & 1.5 & 0.8 & 0.1 & 0.1 & 5.7 & 10 & 0.7 & 2.6 & 5 & 6.6 & 0.1 & 1.1 \\
\hline Harpacticoida & 3.1 & 13.7 & 2.1 & 1.5 & & & & & 20.8 & 35.2 & 4 & 34.7 & & & & \\
\hline Ostracoda & 7.7 & 6.4 & 1.7 & 1.1 & & & & & 1.9 & 0.7 & 0.2 & 0.1 & & & & \\
\hline \multicolumn{17}{|l|}{ Amphipoda } \\
\hline Paradexamine fisicauda & & & & & 4.4 & 4.8 & 0.9 & 1.1 & 13.2 & 4.5 & 10.7 & 8.5 & & & & \\
\hline Jassa falcata & 13.9 & 5.5 & 7.8 & 5.7 & 10.3 & 18 & 3.7 & 9.5 & 13.5 & 11.3 & 16.4 & 15.5 & 15 & 10.2 & 12.6 & 11.6 \\
\hline Cyllopus magellanicus & 1.5 & 0.3 & 2.5 & 0.2 & 2.9 & 0.5 & 0.6 & 0.1 & 9.4 & 3.6 & 9.1 & 5 & 8.1 & 9.5 & 3.7 & 3.4 \\
\hline Waldeckia obesa & 1.5 & 0.3 & 0.4 & 0.1 & 7.4 & 6.6 & 6.6 & 4.1 & 1.9 & 2.6 & 3.3 & 0.5 & 8.5 & 18.3 & 6 & 6.2 \\
\hline Gondogeneia antarctica & 3.1 & 1.2 & 8 & 0.9 & & & & & 9.4 & 7.4 & 6.2 & 5.4 & 7.5 & 5.1 & 2.1 & 1.9 \\
\hline Eusirus antarcticus & & & & & 4.4 & 6.1 & 2.1 & 1.5 & & & & & & & & \\
\hline Orchomenella nana & & & & & 7.4 & 5 & 3.4 & 2.6 & & & & & & & & \\
\hline Bovallia gigantea & & & & & 8.8 & 3.2 & 2.7 & 2.2 & & & & & & & & \\
\hline Primno macropa & & & & & 1.5 & 2.4 & 0.3 & 0.2 & 17 & 5.8 & 5 & 7.8 & & & & \\
\hline Caprellidea (unidentified) & & & & & 5.9 & 2.4 & 0.5 & 0.7 & 7.6 & 4.8 & 2.8 & 2.5 & & & & \\
\hline $\begin{array}{l}\text { Unidentified amphipods } \\
\text { Isopoda }\end{array}$ & 12.3 & 6.1 & 9.7 & 6 & 14.7 & 11.1 & 4.1 & 9.5 & 1.9 & 1 & 1.2 & 0.2 & 2.5 & 1.5 & 0.1 & 0.1 \\
\hline Glyptonotus acutus & & & & & 8.8 & 3.4 & 13.6 & 6.5 & 5.7 & 2.3 & 2.6 & 1.2 & 2.5 & 0.7 & 0.4 & 0.1 \\
\hline Glyptonotus antarcticus & 4.6 & 1.5 & 6.7 & 1.2 & 16.3 & 8.2 & 11.5 & 13.6 & 7.6 & 3.9 & 7.8 & 3.7 & 7.5 & 6.6 & 1.7 & 2.1 \\
\hline Serolis sp. & 24.6 & 5.4 & 23.4 & 21.8 & 16.1 & 6.4 & 9.3 & 10.8 & 1.9 & 0.7 & 1.4 & 0.2 & 15 & 7.3 & 9.6 & 8.6 \\
\hline $\begin{array}{l}\text { Unidentified isopods } \\
\text { Euphausiacea }\end{array}$ & 9.2 & 3.2 & 5.7 & 2.5 & 7.4 & 5.3 & 3.6 & 2.8 & 5.7 & 1 & 2.8 & 0.9 & 8 & 1.5 & 1.8 & 0.6 \\
\hline Euphausia superba & 1.5 & 0.3 & 4.4 & 0.4 & 17.7 & 5.3 & 16.1 & 16.1 & 3.8 & 1.3 & 7.8 & 1.5 & 27.5 & 16.1 & 29.5 & 42.7 \\
\hline Teleostei & & & & & & & & & & & & & 7.5 & 2.2 & 11.2 & 3.4 \\
\hline
\end{tabular}

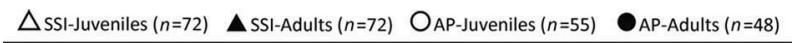

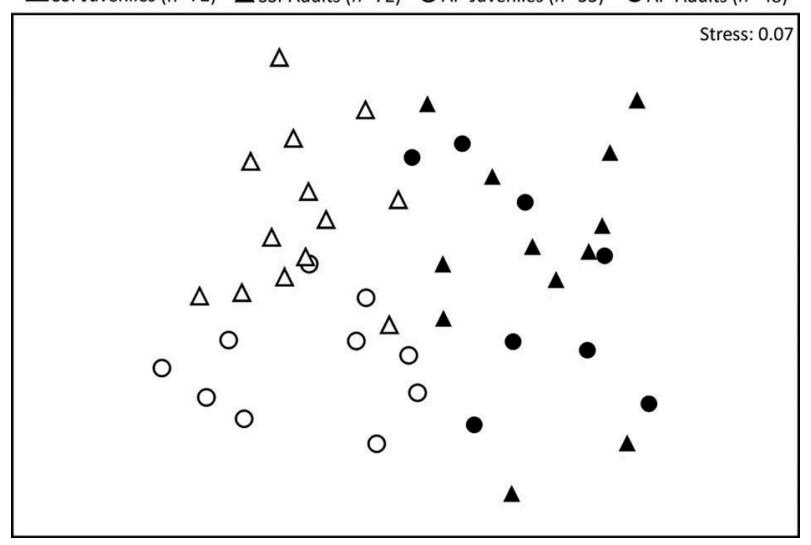

Figure 4. Non-parametric multi-dimensional scaling of Lepidonotothen nudifrons samples based on stomach content analysis, with both areas and ontogenetic stages superimposed.

isopods and calanoid copepods were more consumed off the SSI than in the AP, while cyclopoid copepods were more consumed off the AP than in the SSI. Additionally, other regional differences also were reported by Targett (1981), who found that L. nudifrons preyed on errant polychaetes, shrimps, fish and mysids off South Georgia, and amphipods, isopods, sedentary polychaetes and cumaceans off the South Orkney Islands. In contrast with Targett (1981), shrimps, fishes, mysids and cumaceans are absent in the diet of $L$.
Table 4. Results of NP-MANOVA testing the effect of ontogenetic stage (juvenile, adult) and area on the number and weight of the main prey items (Polychaeta, Copepoda, Amphipoda, Isopoda and Euphausiacea) of Lepidonotothen nudifrons.

\begin{tabular}{|c|c|c|c|c|c|}
\hline \multirow[b]{2}{*}{ Factor } & \multirow[b]{2}{*}{$d f$} & \multicolumn{2}{|c|}{ Prey number } & \multicolumn{2}{|c|}{ Prey weight } \\
\hline & & $F$ & $p$ & $F$ & $p$ \\
\hline Ontogenetic stage & 1 & 7.1239 & $0.0001^{\mathrm{b}}$ & 12.5467 & $0.0001^{b}$ \\
\hline Area & 1 & 1.8639 & $0.0987^{\mathrm{a}}$ & 1.5585 & $0.1421^{\mathrm{a}}$ \\
\hline Ontogenetic stage $\mathrm{x}$ area & 1 & 3.0257 & $0.0121^{b}$ & 3.0125 & $0.0338^{\mathrm{b}}$ \\
\hline Residuals & 243 & & & & \\
\hline Juvenile-AP vs. Adult-AP & 1 & 4.8065 & $0.0004^{b}$ & 3.8806 & $0.0007^{b}$ \\
\hline Residuals & 101 & & & & \\
\hline Juvenile-SSI vs. Adult-SSI & 1 & 5.3657 & $0.0031^{b}$ & 9.7658 & $0.0001^{b}$ \\
\hline Residuals & 142 & & & & \\
\hline Adult-SSI vs. Adult-AP & 1 & 2.4022 & $0.1245^{\mathrm{a}}$ & 1.7202 & $0.1166^{\mathrm{a}}$ \\
\hline Residuals & 118 & & & & \\
\hline Juvenile-SSI vs. Juvenile-AP & 1 & 2.6896 & $0.0294^{b}$ & 2.8106 & $0.0327^{b}$ \\
\hline Residuals & 125 & & & & \\
\hline
\end{tabular}

${ }^{\mathrm{a}}$ Non-significant differences. ${ }^{\mathrm{b}}$ Statistically significant differences $(a=0.05)$.

nudifrons off the SSI and the AP. Such spatial differences might presumably be due to different local abundances (i.e., availability) of potential prey species. Although the relative abundances of the major suprabenthic and zooplanktonic taxa (i.e., Mysida, Amphipoda, Cumacea, Isopoda and Copepoda) are comparable, they are highly variable in the investigated areas (Linse et al. 2002; Lörz \& Brandt 2003; Calbet et al. 2005; Rehm et al. 2007; San Vicente et al. 2007). 

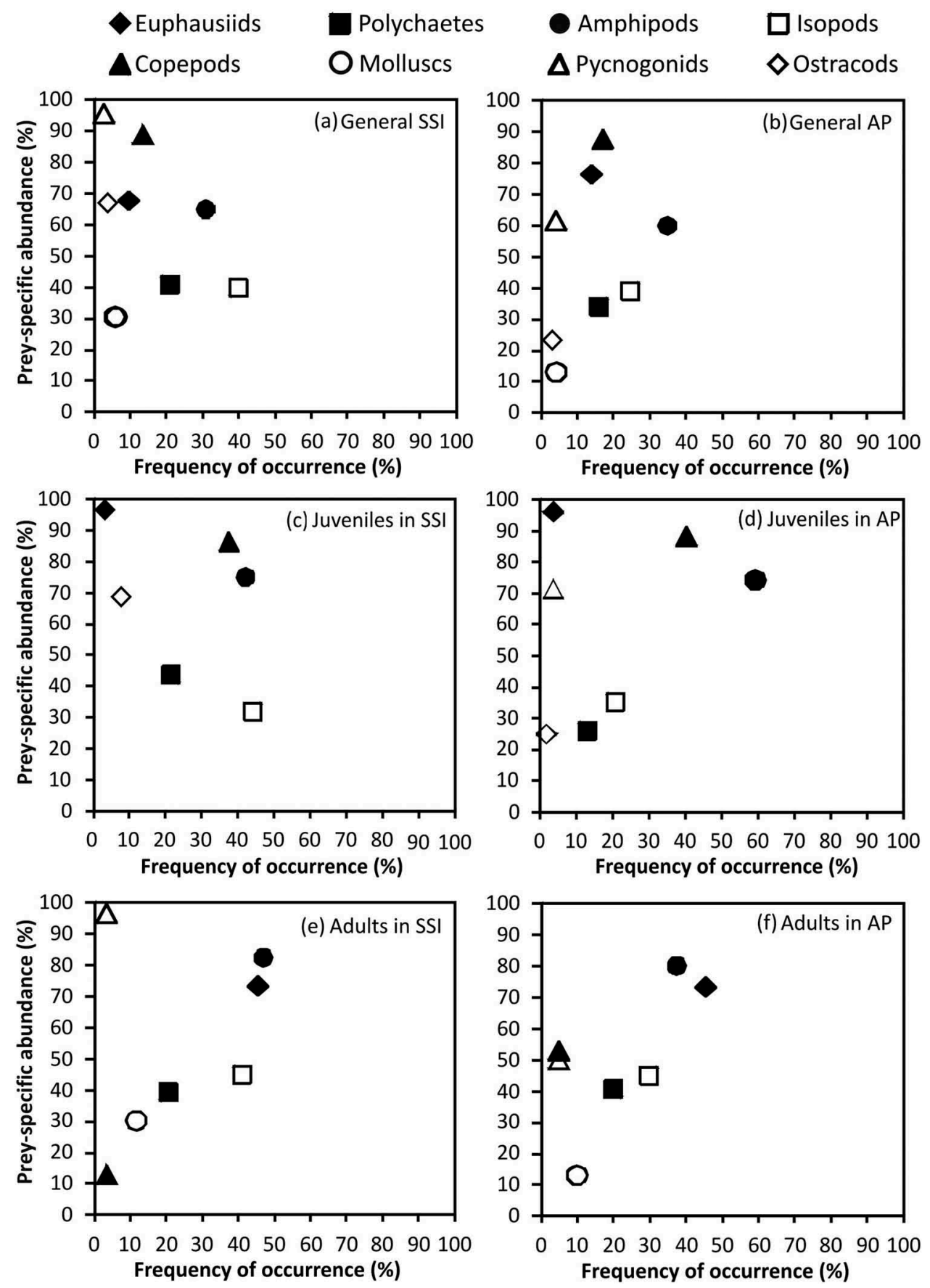

Figure 5. Feeding strategy and importance of prey items in the diet of Lepidonotothen nudifrons with stomach content from the SSI and the AP.

Variations in physical factors such as current direction and speed, sea-ice cover, sediment structure, topography and food supply may cause spatial differences in the composition of assemblages in the Southern Ocean (San Vicente et al. 2009). Bonicelli et al. (2008) showed that the region of the SSI is a dynamic area, where the distribution of zooplankton is strongly related to the water masses characteristic of the Bellingshausen Sea and south-east Weddell Sea. Off the SSI the mesozooplankton community was mostly composed of copepods, dominated by calanoids, whereas in the waters off the AP the dominant copepods were cyclopoids (Ayón et al. 1999; Calbet et al. 2005). Previous studies also showed that isopods are more abundant off the SSI than off the AP (Linse et al. 2002; Lörz \& Brandt 2003; San Vicente et al. 2007).

Ontogenetic changes in the trophic ecology of $L$. nudifrons were observed in both areas, reflected by a decrease in the consumption of copepods and an increase in the consumption of E. superba with fish size. Targett (1981) also provided evidence of an ontogenetic dietary change in L. nudifrons at South Georgia and the South Orkney Islands, where polychaetes and cumaceans were preyed upon by juvenile fish, while mysids, shrimps and fish eggs were eaten by adult fish. Differences in the diet composition of fish of different sizes have also been noted in other notothenioids from the Southern Ocean, such 
as L. larseni, L. squamifrons, Gobionotothen gibberifrons and G. marionensis (Targett 1981; Takahashi \& Iwami 1997; Bushula et al. 2005; Curcio et al. 2014; Gregory et al. 2014). In all these species, as well as $L$. nudifrons, the number of different prey types increased with fish size and may be attributed to morphological constraints (e.g., gape-limited) or the better foraging ability of larger individuals (Knox 2006). The diet changes between the SSI and the AP observed only in the juvenile stage could be related to their limited swimming ability (Fanta \& Meyer 1998), which would reduce their movement between areas. The diet composition of juvenile $L$. nudifrons in SSI mainly comprised amphipod and isopods, as also found by Moreira et al. (2014). Conversely, the calanoid copepods, which we found to be the most important copepods consumed by juvenile fish, were not found in the previous study (Moreira et al. 2014).

A high between-phenotype contribution to the niche width was observed when considering the whole population of L. nudifrons in each sampling area, where individual predators had specialized on different prey types and each food category had been consumed by only a limited fraction of the predators. However size classes were separated in the analysis, $L$. nudifrons showed a more mixed feeding strategy, with different dominant prey for each class and a greater within-phenotype component, with several individuals in the population eating several different types of prey. A similar feeding strategy was described in L. nudifrons off the AP (Daniels 1982), where each ontogenetic stage showed half the prey diversity of the whole population. The adoption of different feeding strategies and taking different prey or amounts of the same prey likely reduces intraspecific competition (La Mesa et al. 1997). Food sharing reflects competition only under conditions of limited resource availability (Ward et al. 2006). According to Casaux et al. (1990) and Knox (2006), during summer there was a high availability of food in this area, which may contribute to reducing intraspecific competition for food (Moreira et al. 2014). Changes in the dominant prey items in the diet of juveniles could be due to differences in availability and abundance of potential prey at different sites, as well as an opportunist strategy, as suggested by Barrera-Oro (2003).

The TR estimated in the present study for $L$. nudifrons $(\mathrm{TR}=3.34)$ allowed this species to be characterized as a secondary consumer $(\mathrm{TR}<4)$. This result indicates that, in the trophic structure of Antarctic communities, L. nudifrons plays an important role in the energy flow from lower to higher TRs, because it is usually preyed by seals, birds and also other fishes (Barrera-Oro 2002). Although an increase in TR related to ontogenetic stage was found in the present study, juveniles and adults were both secondary consumers. Unfortunately, the lack of previous data on the TR of L. nudifrons, and other congeneric species, prevents comparisons among them. Further studies should focus attention on TR estimation throughout the ontogeny of other species of Lepidonotothen in order to provide new insights on the ecological role of each ontogenetic stage within demersal food webs of the Antarctic Zone.

\section{Acknowledgements}

The authors would like to thank to Dr Mario La Mesa and an anonymous referee for their helpful comments that greatly improved early drafts of the manuscript. We also acknowledge to Dr Juan Manuel Molina for helpful revision of grammar style.

\section{Funding}

This work was supported by the Consejo Nacional de Investigaciones Científicas y Técnicas (project FONDO IBOL); Dirección Nacional del Antártico and Instituto Antártico Argentino. GEB was supported by a fellowship from the Consejo Nacional de Investigaciones Científicas y Técnicas.

\section{ORCID}

Gabriela Blasina (D) http://orcid.org/0000-0001-8000-9846

\section{References}

Amundsen P., Gabler H. \& Staldvik F. 1996. A new approach to graphical analysis of feeding strategy from stomach contents data: modification of the Costello (1990) method. Journal of Fish Biology 48, 607-614.

Anderson M. 2001. A new method for non-parametric multivariate analysis of variance. Austral Ecology 26, 32-46.

Ayón P., Girón Gutiérrez M., Arones Flores K. \& Quesquén R. 1999. Composición, abundancia y distribución del zooplancton antártico en el estrecho Bransfield y alrededores de la isla Elefante. Verano Austral 1998. (Composition, abundance and distribution of Antarctic zooplankton in the Bransfield Strait and the waters around Elephant Island. Austral summer 1998.) Perú Antar 9, 47-62.

Barrera-Oro E. 2002. The role of fish in the Antarctic marine food web: differences between inshore and offshore waters in the southern Scotia Arc and west Antarctic Peninsula. Antarctic Science 14, 293-309.

Barrera-Oro E. 2003. Analysis of dietary overlap in Antarctic fish (Notothenioidei) from the South Shetland Islands: no evidence of food competition. Polar Biology 26, 631-637.

Barrera-Oro E. \& Winter D. 2008. Age composition and feeding ecology of early juvenile Notothenia rossii (Pisces, Nototheniidae) at Potter Cove, South Shetland Islands, Antarctica. Antarctic Science 20, 339-341.

Boltovskoy D. 1999. South Atlantic zooplankton. Leiden: Backhuys Publishers.

Bonicelli P., Lopez J., Ochoa D., Shreeve N. \& Rachael S. 2008. Estructura comunitaria del zooplancton asociada con el fitoplancton y las masas de agua del estrecho Bransfield y la isla elefante durante el verano austral del 2006. (Community structure of zooplankton associated 
with phytoplankton and water masses in the Bransfield Strait and around Elephant Island during the austral summer of 2006.) Ecología Aplicada 7, 159-164.

Bushula T., Pakhomov E.A., Kaehler S., Davis S. \& Kalin R. M. 2005. Diet and daily ration of two nototheniid fish on the shelf of the sub-Antarctic Prince Edward Islands. Polar Biology 28, 585-593.

Calbet A., Alcaraz M., Atienza D., Broglio E. \& Vaqué D. 2005. Zooplankton biomass distribution patterns along the western Antarctic Peninsula (December 2002). Journal of Plankton Research 27, 1195-1203.

Casaux R., Barrera-Oro E., Baroni A. \& Ramón A. 2003. Ecology of inshore notothenioid fish from the Danco Coast, Antarctic Peninsula. Polar Biology 26, 157-165.

Casaux R., Mazzotta A. \& Barrera-Oro E. 1990. Seasonal aspects of the biology and diet of nearshore nototheniid fish at Potter Cove, South Shetland Islands, Antarctica. Polar Biology 11, 63-72.

Cortés E. 1997. A critical review of methods of studying fish feeding based on analysis of stomach contents: application to elasmobranch fishes. Canadian Journal of Fisheries and Aquatic Sciences 54, 726-738.

Cortés E. 1999. Standardized diet compositions and trophic levels of sharks. ICES Journal of Marine Science 56, 707-717.

Costello M.J. 1990. Predator feeding strategy and prey importance: a new graphical analysis. Journal of Fish Biology 36, 261-263.

Curcio N., Tombari A. \& Capitanio F. 2014. Otolith morphology and feeding ecology of an Antarctic nototheniid, Lepidonotothen larseni.. Antarctic Science 26, 124-132.

Daniels R.A. 1982. Feeding ecology of some fishes of the Antarctic Peninsula. Fishery Bulletin 80, 575-588.

De Witt H.H., Heemstra P.C. \& Gon O. 1990. Nototheniidae. In O. Gon \& P. C. Heemstra (eds.): Fishes of the Southern Ocean. Pp. 279-331. Grahamstown: J.L.B. Smith Institute of Ichthyology.

Eastman J.T. 2005. The nature of the diversity of Antarctic fishes. Polar Biology 28, 93-107.

Ebert D.A. \& Bizzarro J.J. 2007. Standardized diet compositions and trophic levels of skates (Chondrichthyes: Rajiformes: Rajoidei). Environmental Biology of Fishes 80, 221-237.

Fanta E. \& Meyer A.A. 1998. Behavioural strategies for feeding of six species of the Antarctic fish family Nototheniidae (Pisces, Notothenioidei) in a tank. Antarctic Record 42, 227-243.

Gregory S., Brown J. \& Belchier M. 2014. Ecology and distribution of the grey notothen, Lepidonotothen squamifrons, around South Georgia and Shag Rocks, Southern Ocean. Antarctic Science 26, 239-249.

Heath M.R., Neat F.C., Pinnegar J.K., Reid D.G., Sims D. W. \& Wright P.J. 2012. Review of climate change impacts on marine fish and shellfish around the UK and Ireland. Aquatic Conservation: Marine and Freshwater Ecosystems 22, 337-367.

Hourigan T.F. \& Radtke R.L. 1989. Reproduction of the Antarctic fish Nototheniops nudifrons. Marine Biology 100, 277-283.

Hyslop E.J. 1980. Stomach contents analysis - a review of methods and their application. Journal of Fish Biology 17, 411-429.

Knox G.A. 2006. Biology of the Southern Ocean. 2nd edn. London: CRC Press.

Kock K.H., Barrera-Oro E., Belchier M., Collins M.A., Duhamel G., Hanchet S., Pshenichnov L., Welsford D. \& Williams R. 2012. The role of fish as predators of krill (Euphausia superba) and other pelagic resources in the southern ocean. CCAMLR Science 19, 115-169.
La Mesa M., Eastman J.T. \& Vacchi M. 2004. The role of notothenioid fish in the food web of the Ross Sea shelf waters: a review. Polar Biology 27, 321-338.

La Mesa M., Vacchi M., Castelli A. \& Diviacco G. 1997. Feeding ecology of two nototheniid fishes, Trematomus hansoni and Trematomus loennbergii, from Terra Nova Bay, Ross Sea. Polar Biology 17, 62-68.

Linse K., Brandt A., Hilbig B. \& Wegener G. 2002. Composition and distribution of suprabenthic fauna in the south-eastern Weddell Sea and off King George Island. Antarctic Science 14, 3-10.

Llompart F., Delpiani M., Lattuca E., Delpiani G., CruzJiménez A., Orlando P., Ceballos S., Díaz De Astarloa J.M., Vanella F. \& Fernández D. 2015. Spatial patterns of summer demersal fish assemblages around the Antarctic Peninsula and South Shetland Islands. Antarctic Science 27, 109-117.

Lörz A.-N. \& Brandt A. 2003. Diversity of Peracarida (Crustacea, Malacostraca) caught in a suprabenthic sampler. Antarctic Science 15, 433-438.

Molinero A. \& Flos R. 1992. Influence of season on the feeding habits of the common sole Solea solea. Marine Biology 113, 499-507.

Moreira E., Juáres M. \& Barrera-Oro E. 2014. Dietary overlap among early juvenile stages in an Antarctic notothenioid fish assemblage at Potter Cove, South Shetland Islands. Polar Biology 37, 1507-1515.

Okach J.O. \& Dadzie S. 1988. The food, feeding habits and distribution of a siluroid catfish, Bagrus docmac (Forsskal), in the Kenya waters of Lake Victoria. Journal of Fish Biology 32, 85-94.

Pauly D., Christensen V., Froese R. \& Palomares M. 2000. Industrial fishing over the past half-century has noticeably depleted the topmost links in aquatic food chains. Fishing down aquatic food webs. American Scientist 88, 46-51.

Pinkas L., Oliphant M.S. \& Iverson I.L.K. 1971. Food habits of albacore, bluefin tuna and bonito in California waters. Fishery Bulletin. Vol. 152. Sacramento: State of California, Department of Fish and Game.

R Development Core Team 2012. R: a language and environment for statistical computing. Version 2.14.2. Vienna: R Foundation for Statistical Computing.

Rehm P., Thatje S., Mühlenhardt-Siegel U. \& Brandt A. 2007. Composition and distribution of the peracarid crustacean fauna along a latitudinal transect off Victoria Land (Ross Sea, Antarctica) with special emphasis on the Cumacea. Polar Biology 30, 871-881.

San Vicente C., Castelló J., Corbera J., Jimeno A., Munilla T., Sanz C., Sorbe J.C. \& Ramos A. 2007. Biodiversity and structure of the suprabenthic assemblages from South Shetland Islands and Bransfield Strait, Southern Ocean. Polar Biology 30, 477-486.

San Vicente C., Munilla T., Corbera J., Sorbe J.-C. \& Ramos A. 2009. Suprabenthic fauna from the Bellingshausen Sea and western Antarctic Peninsula: spatial distribution and community structure. Scientia Marina 73, 357-368.

Takahashi M. \& Iwami T. 1997. The summer diet of demersal fish at the South Shetland Islands. Antarctic Science 9, 407-413.

Targett T.E. 1981. Trophic ecology and structure of coastal Antarctic fish communities. Marine Ecology Progress Series 4, 243-263.

Ward A.J.W., Webster M.M. \& Hart P.J.B. 2006. Intraspecific food competition in fishes. Fish and Fisheries 7, 231-261.

Zar J.H. 2010. Biostatistical analysis. 5th edn. Upper Saddle River, NJ: Prentice Hall.

Zuur A.F., Ieno E.N. \& Smith G.M. 2007. Analysing ecological data. New York: Springer. 